\title{
Increased mortality in schizophrenia due to cardiovascular disease - a non-systematic review of epidemiology, possible causes, and interventions
}

\author{
Petter Andreas Ringen ${ }^{1,2}$, John A. Engh ${ }^{3}$, Astrid B. Birkenaes ${ }^{1}$, Ingrid Dieset ${ }^{1,2}$ and Ole A. Andreassen ${ }^{1,2 *}$ \\ ${ }^{1}$ NORMENT, KG Jebsen Centre for Psychosis Research, Oslo University Hospital and Institute of Clinical Medicine, University of Oslo, Oslo, Norway \\ ${ }^{2}$ Division of Mental Health and Addiction, Oslo University Hospital, Oslo, Norway \\ ${ }^{3}$ Division of Mental Health and Addiction, Vestfold Hospital Trust, Tonsberg, Norway
}

Edited by:

Jørn Heggelund, Trondheim

University Hospital, Norway

Reviewed by:

Lars Lien, National Center for Dual

Diagnosis, Norway

Steve Brown, Southern Health

Foundation, UK

${ }^{*}$ Correspondence:

Ole A. Andreassen, Oslo

universitetssykehus HF, Klinikk

psykisk hele og avhengighet, Sekjson

for psykoseforskning/TOP, Ullevål

sykehus, bygg 49, Postboks 4956

Nydalen, 0424 Oslo, Norway

e-mail: o.a.andreassen@medisin.

uio.no
Background: Schizophrenia is among the major causes of disability worldwide and the mortality from cardiovascular disease (CVD) is significantly elevated. There is a growing concern that this health challenge is not fully understood and efficiently addressed.

Methods: Non-systematic review using searches in PubMed on relevant topics as well as selection of references based on the authors' experience from clinical work and research in the field.

Results: In most countries, the standardized mortality rate in schizophrenia is about 2.5, leading to a reduction in life expectancy between 15 and 20 years. A major contributor of the increased mortality is due to CVD, with CVD mortality ranging from 40 to $50 \%$ in most studies. Important causal factors are related to lifestyle, including poor diet, lack of physical activity, smoking, and substance abuse. Recent findings suggest that there are overlapping pathophysiology and genetics between schizophrenia and CVD-risk factors, further increasing the liability to CVD in schizophrenia. Many pharmacological agents used for treating psychotic disorders have side effects augmenting CVD risk. Although several CVD-risk factors can be effectively prevented and treated, the provision of somatic health services to people with schizophrenia seems inadequate. Further, there is a sparseness of studies investigating the effects of lifestyle interventions in schizophrenia, and there is little knowledge about effective programs targeting physical health in this population.

Discussion: The risk for CVD and CVD-related deaths in people with schizophrenia is increased, but the underlying mechanisms are not fully known. Coordinated interventions in different health care settings could probably reduce the risk. There is an urgent need to develop and implement effective programs to increase life expectancy in schizophrenia, and we argue that mental health workers should be more involved in this important task.

Keywords: schizophrenia, mortality, metabolic syndrome X, physical training, lifestyle, cardiovascular diseases

\section{INTRODUCTION}

Schizophrenia is a major public health concern, causing extensive suffering and a large need for costly treatment and care. Schizophrenia is among the top 10 causes of disability adjusted life years (DALYs) worldwide (1). The standardized mortality rate (SMR) calculated by dividing the observed mortality of a cohort by the expected mortality of an age- and gender-matched cohort of the general population is considerably elevated in schizophrenia. Today, the largest single cause of death in schizophrenia is cardiovascular disease (CVD) $(2,3)$, similar to the general population. The aim of this paper is to review clinical and epidemiological evidence for increased CVD mortality in schizophrenia, possible causes and mechanisms, available treatments and preventions, and focus the discussion on development and implementation of effective interventions to increase life expectancy in schizophrenia.

\section{METHODS}

We conducted a non-systematic review. We used PubMed search terms including "schizophrenia" and "mortality" or "CVD," "somatic health," "screening and interventions," and included publications selected based on knowledge generated from our research in this field as well as clinical experience from working with people with schizophrenia.

\section{GENERAL MORTALITY IN SCHIZOPHRENIA}

Meta-analyses have reported a 2.5- to 3-fold increase in mortality ratios in schizophrenia (4-8), in both inpatient and outpatient settings (9). In a recent survey from Australia including 7000 individuals with psychosis, all deaths in an observation period was registered and SMR was calculated to be as high as 5.5 (65 deaths), with even higher rates for young adults (SMR 15; 8-15 deaths) (10). These mortality ratios are alarming and higher than reported 
in other similar studies. Possibly, this discrepancy may reflect real variations in SMR in different sub-populations within psychosis spectrum disorders.

Life expectancy for people with schizophrenia is estimated to be about 15-20 years shorter than for the general population $(2,11)$. A particular cause for concern is that the mortality gap between the general population and schizophrenia seems to have increased during the last decades $(8,12)$. Death from unnatural causes appears to be 10-20 times higher in schizophrenia than in the general population $(2,4,13)$. Suicide and accidents accounted for about $40 \%$ of the extra deaths, while $60 \%$ were from natural causes $(4,8,14,15)$.

Increased mortality from natural causes is not a recent phenomenon; two large Scandinavian studies from the first part of the twentieth century found significantly increased SMRs of 2.1 $(16,17)$ and $4.0(16,17)$. The main causes of death were tuberculosis and pneumonia. The high mortality was ascribed to the general disease prevalence and lack of antibiotics but also to the overcrowding, malnutrition, and poor hygiene of large psychiatric institutions.

\section{CARDIOVASCULAR DISEASE-RELATED DEATHS IN SCHIZOPHRENIA}

Several cohort studies addressing the CVD-related mortality have been conducted during the last decade. A large retrospective study from the UK including 46,000 people with a severe mental disorder (schizophrenia-spectrum and -bipolar disorder), and 300,000 controls found the hazard ratios for CVD mortality to be threefold for the age group 18-49 years and twofold for the age group 50-75 years (18). A retrospective register study from Stockholm county in Sweden including 7800 persons with schizophrenia found CVD to be the main cause of death with a SMR of 2.3 and 2.1 for males and females, respectively (13). A more recent prospective national register study from Sweden involving 8300 persons with schizophrenia found hazard ratios for CVD mortality to be 3.3 ( 12 years reduced life expectancy) for women and 2.2 (15 years reduced life expectancy) for men (19). Another recent prospective study from Sweden, Finland, and Denmark using registers found similar SMRs (range 1.6-2.5) for CVD-related deaths in all the three countries, and life expectancies were 15-20 years shorter than in the general population (11). The increased rates of CVD-related deaths have been confirmed also in autopsy studies (20).

\section{POSSIBLE CAUSES OF INCREASED RISK FOR CVD-RELATED DEATHS IN SCHIZOPHRENIA \\ METABOLIC SYNDROME AND OBESITY}

The metabolic syndrome (MetS) is best seen as a physiological change with a clustering of interrelated metabolic risk factors for developing type-2 diabetes and CVD, as well as a variety of other disorders. The main risk factors are abdominal obesity, elevated blood pressure, dyslipidemia, and insulin resistance, but lately other mechanisms such as endothelial dysfunction, inflammatory activity, and stress are also recognized as important components (21).

Over the last 10 years, schizophrenia has consistently been shown to be associated with a raised prevalence of the MetS (2225). McEvoy and colleagues (24) reported on baseline findings from 686 persons with chronic schizophrenia in the CATIE Study, where the prevalence of MetS was over 35\% in males and over $50 \%$ in females. Saari and colleagues (25) found that people with schizophrenia from the Northern Finland 1966 Birth Cohort Study had a fourfold risk of the MetS and that the risk was particularly increased in young individuals. A recent meta-analysis by Mitchell and colleagues investigated the prevalence of specific CVD-risk factors in a schizophrenia population who was either unmedicated $(n=1325)$, in first episode $(n=2548)$, or in the chronic phase ( $n=24892$ ) to a healthy population. They found that about $25 \%$ of the unmedicated and first-episode groups were either overweight, had elevated blood pressure, or dyslipidemia. This prevalence rate is lower compared to the chronic group, but higher compared to an age-matched healthy population (26). However, the same study reported that the prevalence of type- 2 diabetes and hyperglycemia was the same in young people with schizophrenia and their healthy peers (26).Taken together, these and other results may suggest that the increased prevalence of type- 2 diabetes in schizophrenia is related to treatment with second-generation antipsychotics (AP) (27). However, others have shown that first-episode, drug-naive patients with schizophrenia have impaired fasting glucose tolerance, more insulin resistance, and higher levels of plasma glucose compared to healthy controls (28).

High CVD morbidity is also found in patients with mental disorders other than schizophrenia. In a sample of middle-aged and older patients with psychotic symptoms, the risk for CVD was increased by $60-70 \%$ in patients with mood disorder or post-traumatic stress disorder (PTSD) relative to the Framingham 10-year risk of CVD (29). In a Finnish study, the prevalence of MetS in depressed patients was 36\% (30). CVD-risk in a sample of people with major depressive disorder or bipolar disorder increased with $50 \%$ from pre-treatment to 2-year follow-up (31).

Obesity, part of the MetS, is more prevalent among people with schizophrenia than in the general population (32). Important causes for obesity include excessive levels of food intake, physical inactivity, as well as genetic disposition and an imbalanced interplay between hormones (insulin, leptin, and adiponectin) and several inflammatory markers (including interleukins, the tumor necrosis factor family, and C-reactive protein) $(21,33)$.

In this review, the different components of the MetS and obesity are further discussed in the specific chapters.

\section{LIFESTYLE}

\section{Tobacco smoking and substance use}

Smoking has well-known detrimental effects on CVD-risk profile and mortality $(34,35)$. Tobacco smoking is about three times more prevalent in people with schizophrenia than in the general population, and the amount of smoking is also higher among smokers (22, 36-38). While tobacco smoking has seen a downturn in the general population (39), smoking rates do not seem to decline in people with schizophrenia (40). In a recent Finnish survey of psychotic disorder, smoking at baseline, along with diabetes, was found to be the most important predictor of 8 -year mortality (41). Tobaccorelated conditions comprised approximately $53 \%$ of total deaths in people with schizophrenia in a recent large cohort study (42).

Prevalence of substance abuse is also high in schizophrenia (38), and this is problematic as substance use in itself is associated with lower psychosocial functioning $(43,44)$, higher risk of 
exacerbations, or relapses and may also have direct adverse somatic effects (45-48). Recently, mortality from natural causes was found to be especially high in patients with comorbid substance use disorders (49). However, cannabis use was in one study reported to be associated with decreased mortality in psychotic disorder, which was tentatively associated with anti-inflammatory effects of the endocannabinoid system (50). The most commonly used illicit substance in schizophrenia is cannabis, followed by amphetamines and cocaine $(38,51)$, although availability and preferences vary across nations and regions.

The increased substance use and smoking in schizophrenia may partly be explained by altered reward-seeking behavior and deficits in the representation of value of stimuli $(52,53)$. This is in line with the Reward Deficiency Syndrome model proposed for substance abuse (54), which seems to be associated with the pathophysiology of schizophrenia (55) and the biological pathways implicated in nicotine dependence and smoking cessation (56). This model also suggests treatment strategies (54), which may also have implications for interventions targeting other CVD-risk factors.

\section{Physical inactivity and poor diet}

Schizophrenia is associated with sedentary behavior (57). The engagement in recommended weekly physical activity was estimated to $26 \%$ in people with schizophrenia (58), which was lower than in the general population (34\%) (59). Other studies applying different assessment tools have also shown that people with schizophrenia are less active $(60,61)$ and exercise less $(62,63)$. Low levels of physical activity and lack of physical fitness reduce life expectancy and increase risk for MetS and CVD in the general population (64) as well as in schizophrenia (65). Negative symptoms typical for schizophrenia include lack of initiative and withdrawal from activities, often leading to a physically less active life. Passivity and inadequate motivation might also hinder the pursuit of a healthy diet. Furthermore, the lack of self-insight in one's own illness (66) might complicate the possibilities for health promoting activities in schizophrenia. During hospital admissions, patients have more symptoms and lower levels of functioning. Activities are often restricted and admissions of longer duration may have considerable impact on activity levels. The nature of an inpatient psychiatric setting has been considered "obesogenic" (67).

Diets rich in calories, fat, and carbohydrates are an important cause for MetS and increased CVD-risk (68). A balanced diet may have potential to reduce the risk for adverse medical conditions (69-71). Unhealthy diets are prevalent in people with schizophrenia (72). Loss of interest in personal hygiene and physical maintenance are also possible reasons. Alterations in the reward system may also contribute to the unhealthy eating patterns (73). There are indications that dietary habits of the mother may affect taste preferences in the offspring (74), and this might add to other factors contributing to unhealthy eating patterns in families.

Poor personal economy is prevalent in schizophrenia $(75,76)$, and high levels of unemployment is an important reason $(77,78)$. Negative symptoms and cognitive deficits are the main reasons for work disability (79). Poverty affects the possibilities to engage in a healthy lifestyle, as access to healthy foods and training facilities is expensive.

\section{ANTIPSYCHOTIC MEDICATION}

With the introduction of chlorpromazine in 1952, the treatment of schizophrenia was revolutionized, and nowadays medication with AP drugs is considered a central element in the treatment of psychotic disorders (80). However, until second-generation antipsychotics (SGAs) became available in the 1990s, improvement of psychosis often came at the cost of extrapyramidal symptoms and tardive dyskinesia, sometimes causing more subjective suffering to patients than the disorder itself, and making adherence to treatment a great challenge. At the turn of the last century, metabolic disturbances associated with SGA became a major concern in the treatment of severe mental disorders. Several meta-analyses have shown APs to have different liabilities of causing weight gain and other metabolic side effects. On a group level, clozapine and olanzapine are considered to be the most obesogenic, closely followed by quetiapine, with risperidone, sertindole, and typical APs in an intermediate position, while aripiprazole, amisulpride, and ziprasidone seem to carry the lowest risk (81-83).

However, most trials have studied previously treated patients with prolonged illness, often receiving co-medication with drugs with their own obesogenic properties. There are few prospective, long-term studies on the effects of different APs on previously drug-naïve patients on strict monotherapy. Several treatment studies have shown results diverging from the apparently clearcut panorama of metabolic side effects mentioned above $(84,85)$. Interestingly, weight gain on olanzapine appeared more rapidly while after 12 months it was the same as haloperidol and risperidone (86). Furthermore, sensitivity to side effects differs with age, gender, and ethnicity, as well as individual factors that are not well understood. In addition, several lines of evidence suggest that SGAs may have exacerbated existing somatic health issues in schizophrenia. Metabolic disturbances, such as diabetes and slow blood sugar uptake, had already been observed and described in the "the mentally insane" of the pre-AP era (87-89). Likewise, the first report on AP-induced obesity, shortly after chlorpromazine had been introduced (90), states that "increase in weight, often considerable, has (previously) been reported with such diverse treatments as insulin shock, cardiazol, and electric convulsive therapy."

Antipsychotics constitute a heterogeneous group of drugs that may influence appetite control, body composition, and metabolic regulation through several pathways, a variety of underlying mechanisms of action have been proposed. As APs have complex pharmacological actions and interact with most biogenic amine receptors in the brain, a large number of candidate receptors have been targeted. Kroeze et al. (91) showed that the most robust predictor of a drug's propensity to induce weight gain was its affinity for the $\mathrm{H}_{1}$-histamine receptor (H1R). Through this mechanism, clozapine and olanzapine have been shown to cause hyperphagia and weight gain in rats by selective stimulation of the intra-neuronal enzyme adenosine monophosphate (AMP)activated protein kinase (AMPK) in the hypothalamus, thereby blocking the action of the anorexigenic hormone leptin (92). In accordance with this, findings from one naturalistic study suggest that females with inherent high levels of leptin and high insulin sensitivity might be protected against the obesogenic properties of olanzapine (93). In addition, weight gain and hyperglycemia might be related to SGA effects on inflammatory pathways (94). 
On the other hand, dyslipidemia has been shown to be significantly associated with olanzapine treatment independently of body mass (95). There are also indications of a direct lipogenic effect of olanzapine caused by increased expression of lipid biosynthesis genes (96).

Despite the obvious risks due to metabolic side effects, AP use has not been consistently shown to increase CVD morbidity or mortality in schizophrenia. Osborn and colleagues (18) concluded that the excess death rates found among mentally ill people could not be explained neither by smoking, social deprivation, nor by the use of AP medication alone, although patients on APs seemed to be at even greater risk than those without. In a recent meta-analysis of drug trials with placebo controls, AP use was not found to be related to increased mortality in schizophrenia, although the higher general mortality in this patient group was replicated (97). Furthermore, two large Finnish registry studies demonstrated reduced mortality from all causes in people with schizophrenia on long-term treatment with APs $(98,99)$. Better somatic care in patients receiving AP medication could be part of the explanation, however, debate continues on the interpretation of these findings and the role of APs in the all-over schizophrenia mortality $(41,100,101)$. In addition, sudden cardiac death in schizophrenia has in several studies been associated with the use of APs, most probably related to arrhythmias (102-104). Not every study confirms this picture; Manu and co-workers (105) found that unexpected deaths in people with schizophrenia most likely was due to coronary events and found no hypermortality related to higher levels of AP-treatment.

\section{SHARED PATHOPHYSIOLOGICAL MECHANISMS IN SCHIZOPHRENIA AND CVD}

Several lines of evidence indicate shared underlying pathobiology between schizophrenia and CVD, beyond the effects accounted for by lifestyle and AP medication.

First, this relationship might be due to common genetic factors that contribute to both comorbid medical conditions and mortality in schizophrenia (106). In particular, there seems to be overlapping genes associated with both increased CVD-risk factors and schizophrenia $(107,108)$. This might explain recent findings that first-episode psychosis patients not treated with AP medication are more likely to have obesity, insulin-resistance, dyslipidemia, and hypertension compared with age-matched healthy controls $(26,109)$, and the pre-AP era findings mentioned above (see Antipsychotic Medication). Recent molecular studies have indicated that there are abnormalities in the glucose metabolism and insulin signaling pathways in subgroups of unmedicated people with schizophrenia indicating a shared genetic vulnerability between type-2 diabetes and schizophrenia in some cases (110). Second, many neurotransmitters (dopamine, serotonin, and histamine) implicated in schizophrenia also have peripheral effects on pancreatic $\beta$-cells and adipocytes, which regulates blood glucose levels, obesity, and lipid levels (111-113). Third, pathways involving the hypothalamic-pituitary-adrenal axis (HPA) might be involved. First-episode psychosis patients have increased cortisol levels (28) possibly due to environmental stress (114) and these alterations in the HPA-axis might account for some of the increased CVD mortality (115). Finally, recent studies have implicated the immune system in severe mental disorders such as schizophrenia $(116,117)$, as well as in CVD (118), and it is possible that the increased CVD-risk associated with schizophrenia is related to inflammatory mechanisms (119).

\section{HELP SEEKING AND ACCESS TO SOMATIC HEALTH SERVICES}

Patients with severe mental disorders report greater difficulty and more barriers in accessing primary health care (120). These patient groups also receive poorer quality of somatic health care services from hospitals. Thus, there is an increased risk for serious conditions to be undiagnosed or inadequately treated $(121,122)$. People with schizophrenia seem to receive less somatic health care also compared to people with other mental disorders (6, 123-125). In schizophrenia, it is shown that treatment and prevention for CVD is suboptimal, and this seems to affect mortality $(126,127)$. This is supported by an increased mortality due to other somatic conditions besides CVD (15).

In the literature, there are a number of reports of people with schizophrenia who appear to experience little pain despite suffering from painful acute medical conditions, such as myocardial infarction (128) or perforated bowel (129). A meta-analysis of 12 studies on pain perception in schizophrenia indicated reduced pain sensitivity (130). The hypoalgesia was also found in drug-free patients, consistent with clinical observations of reduced sensitivity to pain in schizophrenia reported before the introduction of APs. Pain insensitivity is also found in the healthy relatives of patients with schizophrenia, suggesting a genetic component (131). There is a concern that lack of physical pain sensitivity may result in potentially serious medical conditions passing undiagnosed in schizophrenia (132). There is some evidence that the insula, a cortical structure with extensive connections to different parts of the cortex and the limbic system, is affected in schizophrenia. The insula is important in establishing awareness of the body's internal state (interoception) and plays a major role in the processes of pain sensitivity (133). Apart from patient-related barriers, inadequately organized somatic care in the mental health services and an existing culture with little focus on somatic health issues in psychiatric or mental health clinics may be an important part of the explanation $(134,135)$.

\section{INTERVENTION STUDIES}

\section{SMOKING CESSATION}

Reducing smoking-related mortality will require the delivery of effective anti-smoking strategies. Smoking cessation may have considerable impact on CVD death risk, while just a reduction in smoking does not seem to have the same effect $(136,137)$. Both pharmacological and psychosocial interventions for smoking cessation have been found to be useful in helping people with schizophrenia quit smoking, but the evidence for a lasting effects is poor (138). Concerns that individuals with severe mental illness might suffer negative mental consequences when quitting smoking seem to have little scientific support $(139,140)$.

In a Cochrane review of 21 trials (141), pharmacological treatment with bupropion, a dopamine agonist, was found to increase smoking abstinence rates in smokers with schizophrenia. Another pharmacological agent, varenicline, a nicotinic receptor partial agonist, could also facilitate smoking cessation, but with possible 
psychiatric adverse effects. Psychological interventions such as contingent reinforcement might also help people with schizophrenia to quit or reduce smoking in the short-term. At the present time, there are indications that individuals with schizophrenia can stop smoking with appropriate help, although, convincing evidence that such interventions have a long-term benefit is lacking.

\section{INCREASED CARDIORESPIRATORY FITNESS}

Patients with schizophrenia have low levels of physical activity (36). Increased physical exercise has beneficial effect on several CVD-risk factors such as body weight and blood lipid concentrations (142) and may reduce mortality (143). Improvement in physical fitness seems possible in schizophrenia $(144,145)$ and improved physical fitness seems likely to reduce the elevated mortality in this patient group (146). A Cochrane database review concludes that exercise programs are feasible and may improve mental well-being and overall outcome among patients with schizophrenia (145), as well as in mental illness in general (147). Positive results of promoting physical exercise in people with schizophrenia in outpatient and day care settings have also been reported (148-151).

The association between high cardiorespiratory fitness specifically ( $\max$ oxygen uptake - VO $\max$ ) and low risk of CVD (independently of weight reduction) is established in healthy men and women (152). Studies have shown that people with schizophrenia have reduced peak oxygen uptake, but are capable of participating in physical exercise programs, which improve their peak oxygen uptake $(153,154)$. The effect of the improvement seems to be comparable with effects of physical training in healthy controls and patients with CVD (153).

\section{DIRECT CONTROL OF NUTRIENT UPTAKE AND EXPENDITURE: DIET, EXERCISE, MEDICATION, AND SURGERY}

Obesity is a condition mainly caused by a relative excess intake of calories versus energy expenditure. A focus on these parameters (diet and activity) is therefore a natural starting point for prevention and treatment. Effective weight management may best be reached by the implementation of several measures in an integrated fashion. As there is a complex interplay between the factors responsible for obesity and the other components of the MetS (e.g., hypertension, dyslipidemia, insulin intolerance), effective interventions will be expected to have effects on several CVD-risk factors. Diet modifications may hold some of the same benefits as physical activity for reducing CVD-risk (71). Specific diets (e.g., Mediterranean, nut-enriched) may be favorable in achieving effects on different aspects of the MetS (155-157).

Studies have shown that weight reduction is possible when applying specific intervention programs for individuals with psychotic disorders $(149,158)$. The combined effect of behavioral intervention, nutritional information, and physical exercise was investigated in a study of people with schizophrenia and body mass index (BMI) exceeding 25. The 3-month intervention program showed significant reduction in weight and BMI, which lasted 12 months (159). Intriguingly, weight reduction was gradual, with increasing weight loss as the program progressed, in contrast to weight reductions patterns in diet programs in healthy individuals, where there is often a larger reduction of weight early on.
People with schizophrenia treated with atypical APs participated in a 1-year multimodal weight control program, comprising nutrition, exercise, and behavioral interventions. Clinically significant reductions in weight and other risk factors for poor somatic health, including hemoglobin A1c were found in the patients who participated in the program. In contrast, patients who did not receive the weight control intervention continued to gain weight (160). A Cochrane review investigating the effects of 23 randomized controlled trials found that modest weight reduction can be obtained in people with schizophrenia with selective pharmacological and psychological interventions both on diet and activity levels (161).

For established obesity or MetS, pharmacological and surgical treatment may be needed and constitute important adjunctive measures. Finding safe and effective pharmacological interventions is difficult. Several drugs have been tested for weight reduction. There is evidence for some efficacy for different classes of drugs currently on the market such as, e.g., lipase inhibitors (Orlistat), antidepressants (Lorcaserin, Bupropion), anticonvulsants (Topiramat), and also Metformin for the treatment of comorbid diabetes $(162,163)$. However, there are problems with the evidence for sustained effects as most studies have $<24$ months follow-up. Amphetamine-like appetite suppressants (e.g., phentermin) are now mostly banned in western countries because of the potential for abuse and should probably be avoided in persons vulnerable to psychosis. Sibutramin was withdrawn from the European markets in 2010 because of cardiovascular side effects. There is some evidence that medication and low caloric diet interventions are better than exercise or dietary supplements in maintaining weight loss (164). Statins may be considered for treatment of dyslipidemia in schizophrenia. Available evidence suggests similar treatment response as in the general population (165).

New insights in the metabolism of fats have led to investigation of the role of the hormone leptin in weight loss; however, any possible effect seems to be limited only to individuals with a genetic altered metabolism of leptin $(166,167)$. Alternative classes of drugs are under investigation for weight reduction in AP-induced weight gain in schizophrenia and may hold promise $(168,169)$. Studies in schizophrenia are limited and lack data on long-term effects. However, when other efforts to reduce weight gain have failed, the use of medication, and perhaps especially Metformin, seems to have some support in available evidence from systematic reviews and meta-analyses (170-172). However, no medication for obesity has been shown to reduce CVD morbidity or mortality (173).

Bariatric surgery, where parts of the digestive system are removed or bypassed, seems to provide greater weight reduction and higher rates of remission of type-2 diabetes and MetS compared to non-surgical interventions according to a recent meta-analysis limited to 2 years of follow-up (174). There are preliminary indications that people with schizophrenia receiving this kind of surgery may have similar outcomes as the general population (175).

\section{CLINICAL MONITORING}

There seems to be a consensus that in patients receiving AP medications, weight, blood glucose, blood pressure, and lipid levels should be assessed at baseline and monitored regularly. American 
Diabetes Association et al. (176) recommended that weight should be assessed 4, 8, and 12 weeks after initiating or changing AP medication and quarterly thereafter. Blood pressure, blood glucose, and lipid levels were to be checked 3 months after initiating AP therapy. If normal, blood pressure and blood glucose levels should be assessed every year or more frequently, and lipid levels should be measured every 5 years or more frequently. Several countries have implemented national guidelines with similar recommendations, but the compliance with these guidelines is uncertain (177).

Dealing with the described barriers to adequate somatic health care for people with schizophrenia could include improving availability of personnel skilled in detecting signs of CVD as well as the implementation of routines for checking CVD-risk factors in the mental health care settings. Current evidence makes it relevant to consider implementing such assessments also in people with schizophrenia not receiving AP medication.

If the assessments reveal increased risk factors, several courses of action are possible and should be planned according to the needs of the individual patient. However, important measures will often include change of medication and specific treatment of the present risk factors according to established guidelines for each condition.

\section{DISCUSSION}

The present evidence provides a clear picture of an increased mortality rate in schizophrenia, approximately two to three times higher than in the general population. The majority of the increase is due to CVD. This is a serious health care issue that has to be dealt with. The precise origin of the raised vulnerability to CVD in schizophrenia remains elusive and most likely cannot be attributed to a single mechanism. In the interpretation of the findings of increased mortality, there is a problem that very little research is done on drug-naïve patients, and the full role of AP medications in these associations is thus problematic to assess. At present, most authors agree that the causality is multifactorial. Unfortunately, it is difficult with targeted interventions before the mechanisms are better known. However, the current review of the causative factors indicates that there may be several points of action available for the primary prevention of the increased risk for CVD.

Treatment strategies for reducing the risk-increasing behavior are easy to implement with few side effects, and, thus, potentially widely acceptable. However, even though adequate facilities for physical activities are available, and diet and smoking cessation programs are conducted, patients do not necessarily take advantage of them. Motivation is needed for a change in behavior. Many patients are ambivalent or lack motivation to increase their physical activity. Health care professionals are thus challenged to assist patients in their motivational process. The cognitive technique Motivational Interviewing (178) is increasingly being used in areas of medicine where change in the patients' behavior is important (179-181), and the results of pilot studies in cardiology are promising (182). The Transtheoretical Model of Change describes the motivational process and seems applicable in physical activity programs in severe mental illness populations (183). There are, however, several other obstacles for lifestyles changes among patients with severe mental illness than the motivational factors. Increased symptom load in general, side effects of medication, socioeconomic problems, staff attitudes, and practical problems related to provision of services also represent barriers (184). These should be included in intervention programs.

Secondary prevention of CVD would focus on detection of the increased somatic risk factors and ease the access to prevention and treatment. Of interest, there is research on possible future psychiatry-specific forms for biological treatment for the increased CVD-risk associated with APs (185). The prescription of medication with potential metabolic side effects should only be done after a careful cost-benefit analysis for each individual. Special attention should be paid for drug-naïve patients as well as patients in older age $(80,186)$. Psychotropic medication should be followed by a rigorous monitoring of side effects and changes in CVD-risk factors, following established guidelines $(187,188)$. Findings that the increase in CVD-risk factors occurs early after start of medication should also guide the monitoring (189). As the use of APs is not the only risk factor for increased CVD, AP-free patients should also be monitored for somatic risk factors.

The continuous development and implementation of guidelines is important, but the evidence also points to a demand for somatic proficiency in physicians working in psychiatry and that other mental health professionals contribute. As a group, people with schizophrenia do not receive adequate treatment for CVD, and improving somatic treatment and care in these patients is the first goal. Access to somatic health care should be improved by identifying local health care barriers and thereafter reducing them. Such barriers may exist both in the organization of the services as well as in the minds of politicians, directors, professionals, and patients. The European Psychiatric Association has called for increased cooperation and shared care between the different healthcare professionals to screen and treat CVD-risk factors and diabetes (190). Improved coordination between caretakers and health care professionals is supported by others $(190,191)$. To obtain an integrated system of care based on a holistic biopsychosocial patient perspective perhaps a complete transformation and reorganization of the current mental health care systems is needed (192). Increasing the awareness of CVD-risk factors among psychiatrists and primary care physicians caring for patients with severe mental illness is also called for (190).

A large fraction of the high mortality in schizophrenia may represent avoidable deaths (193). To meet this serious challenge, better understanding of the underlying mechanisms and improved CVD prevention and treatment are needed. However, better coordination of the health care system is also needed.

\section{ACKNOWLEDGMENTS}

The current study was supported by Oslo University Hospital, Research Council of Norway (\#223273), and South-East Health Authority (\#2013-123). We thank Daniel Quintana at the University of Oslo for help with proof-reading.

\section{REFERENCES}

1. Rossler W, Salize HJ, Van OJ, Riecher-Rossler A. Size of burden of schizophrenia and psychotic disorders. Eur Neuropsychopharmacol (2005) 15:399-409. doi:10.1016/j.euroneuro.2005.04.009

2. Hennekens $\mathrm{CH}$, Hennekens AR, Hollar D, Casey DE. Schizophrenia and increased risks of cardiovascular disease. Am Heart J (2005) 150:1115-21. doi:10.1016/j.ahj.2005.02.007 
3. Laursen TM, Nordentoft M, Mortensen PB. Excess early mortality in schizophrenia. Annu Rev Clin Psychol (2014) 10:425-48. doi:10.1146/annurevclinpsy-032813-153657

4. Brown S. Excess mortality of schizophrenia. A meta-analysis. Br J Psychiatry (1997) 171:502-8. doi:10.1192/bjp.171.6.502

5. Bushe CJ, Taylor M, Haukka J. Mortality in schizophrenia: a measurable clinical endpoint. J Psychopharmacol (2010) 24:17-25. doi:10.1177/1359786810382468

6. Laursen TM, Munk-Olsen T, Vestergaard M. Life expectancy and cardiovascular mortality in persons with schizophrenia. Curr Opin Psychiatry (2012) 25:83-8. doi:10.1097/YCO.0b013e32835035ca

7. McGrath J, Saha S, Chant D, Welham J. Schizophrenia: a concise overview of incidence, prevalence, and mortality. Epidemiol Rev. (2008) 30:67-76. doi:10.1093/epirev/mxn001

8. Saha S, Chant D, McGrath J. A systematic review of mortality in schizophrenia: is the differential mortality gap worsening over time? Arch Gen Psychiatry (2007) 64:1123-31. doi:10.1001/archpsyc.64.10.1123

9. Crump C, Ioannidis JP, Sundquist K, Winkleby MA, Sundquist J. Mortality in persons with mental disorders is substantially overestimated using inpatient psychiatric diagnoses. J Psychiatr Res (2013) 47:1298-303. doi:10.1016/j. jpsychires.2013.05.034

10. Saha S, Whiteford H, McGrath J. Modelling the incidence and mortality of psychotic disorders: data from the second Australian national survey of psychosis. Aust N Z J Psychiatry (2014) 48:352-9. doi:10.1177/0004867413513341

11. Laursen TM, Wahlbeck K, Hallgren J, Westman J, Osby U, Alinaghizadeh H, et al. Life expectancy and death by diseases of the circulatory system in patients with bipolar disorder or schizophrenia in the Nordic countries. PLoS One (2013) 8:e67133. doi:10.1371/journal.pone.0067133

12. Hoye A, Jacobsen BK, Hansen V. Increasing mortality in schizophrenia: are women at particular risk? A follow-up of 1111 patients admitted during 19802006 in Northern Norway. Schizophr Res (2011) 132:228-32. doi:10.1016/j. schres.2011.07.021

13. Osby U, Correia N, Brandt L, Ekbom A, Sparen P. Mortality and causes of death in schizophrenia in Stockholm county, Sweden. Schizophr Res (2000) 45:21-8. doi:10.1016/S0920-9964(99)00191-7

14. Leucht S, Burkard T, Henderson J, Maj M, Sartorius N. Physical illness and schizophrenia: a review of the literature. Acta Psychiatr Scand (2007) 116:317-33. doi:10.1111/j.1600-0447.2007.01095.x

15. Tran E, Rouillon F, Loze JY, Casadebaig F, Philippe A, Vitry F, et al. Cancer mortality in patients with schizophrenia: an 11-year prospective cohort study. Cancer (2009) 115:3555-62. doi:10.1002/cncr.24383

16. Alstrõm CH. Mortality in Mental Hospitals with Special Regard to Tuberculosis. Acta Psychiatrica and Neurologica Scandinavica: Supplementum 4. (1942).

17. Odegard O. Mortality in Norwegian mental hospitals 1926-1941. Acta Genet Stat Med (1951) 2:141-73.

18. Osborn DP, Levy G, Nazareth I, Petersen I, Islam A, King MB. Relative risk of cardiovascular and cancer mortality in people with severe mental illness from the United Kingdom's general practice research database. Arch Gen Psychiatry (2007) 64:242-9. doi:10.1001/archpsyc.64.2.242

19. Crump C, Sundquist K, Winkleby MA, Sundquist J. Comorbidities and mortality in bipolar disorder: a Swedish national cohort study. JAMA Psychiatry (2013) 70:931-9. doi:10.1001/jamapsychiatry.2013.1394

20. Sweeting J, Duflou J, Semsarian C. Postmortem analysis of cardiovascular deaths in schizophrenia: a 10-year review. Schizophr Res (2013) 150:398-403. doi:10.1016/j.schres.2013.08.029

21. Kaur J. A comprehensive review on metabolic syndrome. Cardiol Res Pract (2014) 2014:943162. doi:10.1155/2014/943162

22. Birkenaes AB, Opjordsmoen S, Brunborg C, Engh JA, Jonsdottir H, Ringen $\mathrm{PA}$, et al. The level of cardiovascular risk factors in bipolar disorder equals that of schizophrenia: a comparative study. J Clin Psychiatry (2007) 68:917-23. doi:10.4088/JCP.v68n0614

23. Heiskanen T, Niskanen L, Lyytikainen R, Saarinen PI, Hintikka J. Metabolic syndrome in patients with schizophrenia. J Clin Psychiatry (2003) 64:575-9. doi:10.4088/JCP.v64n0513

24. McEvoy JP, Meyer JM, Goff DC, Nasrallah HA, Davis SM, Sullivan L, et al. Prevalence of the metabolic syndrome in patients with schizophrenia: baseline results from the clinical antipsychotic trials of intervention effectiveness (CATIE) schizophrenia trial and comparison with national estimates from NHANES III. Schizophr Res (2005) 80:19-32. doi:10.1016/j.schres.2005.07.014
25. Saari KM, Lindeman SM, Viilo KM, Isohanni MK, Jarvelin MR, Lauren LH, et al. A 4-fold risk of metabolic syndrome in patients with schizophrenia: the Northern Finland 1966 Birth Cohort study. J Clin Psychiatry (2005) 66:559-63. doi:10.4088/JCP.v66n0503

26. Mitchell AJ, Vancampfort D, De HA, Yu W, De HM. Is the prevalence of metabolic syndrome and metabolic abnormalities increased in early schizophrenia? A comparative meta-analysis of first episode, untreated and treated patients. Schizophr Bull (2013) 39:295-305. doi:10.1093/schbul/ sbs082

27. Miron IC, Baroana VC, Popescu F, Ionica F. Pharmacological mechanisms underlying the association of antipsychotics with metabolic disorders. Curr Health Sci J (2014) 40:12-7. doi:10.12865/CHSJ.40.01.02

28. Ryan MC, Collins $\mathrm{P}$, Thakore JH. Impaired fasting glucose tolerance in firstepisode, drug-naive patients with schizophrenia. Am J Psychiatry (2003) 160:284-9. doi:10.1176/appi.ajp.160.2.284

29. Jin H, Folsom D, Sasaki A, Mudaliar S, Henry R, Torres M, et al. Increased Framingham 10-year risk of coronary heart disease in middle-aged and older patients with psychotic symptoms. Schizophr Res (2011) 125:295-9. doi:10.1016/j.schres.2010.10.029

30. Niskanen LK, Hintikka JJ, Koivumaa-Honkanen HT, Honkalampi KM, Haatainen KM, Viinamäki H-T. Metabolic syndrome and depression: a cross-sectional analysis. J Clin Psychiatry (2006) 67:1422-7. doi:10.4088/JCP. v67n0913

31. Taylor V, McKinnon MC, MacDonald K, Jaswal G, MacQueen GM. Adults with mood disorders have an increased risk profile for cardiovascular disease within the first 2 years of treatment. Can J Psychiatry (2010) 55:362-8.

32. Allison DB, Newcomer JW, Dunn AL, Blumenthal JA, Fabricatore AN, Daumit GL, et al. Obesity among those with mental disorders: a national institute of mental health meeting report. Am J Prev Med (2009) 36:341-50. doi:10.1016/j.amepre.2008.11.020

33. Flier JS. Obesity wars: molecular progress confronts an expanding epidemic. Cell (2004) 116:337-50. doi:10.1016/S0092-8674(03)01081-X

34. Beary M, Hodgson R, Wildgust HJ. A critical review of major mortality risk factors for all-cause mortality in first-episode schizophrenia: clinical and research implications. J Psychopharmacol (2012) 26:52-61. doi:10.1177/ 0269881112440512

35. WHO. Global Health Risks: Mortality and Burden of Disease Attributable to Selected Major Risks. Geneva: World Health Organization (2009).

36. De Leon J, Diaz FJ. A meta-analysis of worldwide studies demonstrates an association between schizophrenia and tobacco smoking behaviors. Schizophr Res (2005) 76:135-57. doi:10.1016/j.schres.2005.02.010

37. Lawrence D, Mitrou F, Zubrick SR. Smoking and mental illness: results from population surveys in Australia and the United States. BMC Public Health (2009) 9:285. doi:10.1186/1471-2458-9-285

38. Hartz SM, Pato CN, Medeiros H. Comorbidity of severe psychotic disorders with measures of substance use. JAMA Psychiatry (2014) 71:248-54. doi:10.1001/jamapsychiatry.2013.3726

39. Centers for Disease Contral and Prevention. Cigarette smoking among adults United States, 2006. Morb Mortal Wkly Rep (2007) 56(44):1157-61.

40. Dickerson F, Stallings CR, Origoni AE, Vaughan C, Khushalani S, Schroeder $\mathrm{J}$, et al. Cigarette smoking among persons with schizophrenia or bipolar disorder in routine clinical settings, 1999-2011. Psychiatr Serv (2013) 64:44-50. doi:10.1176/appi.ps.201200143

41. Suvisaari J, Partti K, Perälä J, Viertiö S, Saarni SE, Lönnqvist J, et al. Mortality and its determinants in people with psychotic disorder. Psychosom Med (2013) 75(1):60-7. doi:10.1097/PSY.0b013e31827ad512

42. Callaghan RC, Veldhuizen S, Jeysingh T, Orlan C, Graham C, Kakouris G, et al. Patterns of tobacco-related mortality among individuals diagnosed with schizophrenia, bipolar disorder, or depression. J Psychiatr Res (2014) 48:102-10. doi:10.1016/j.jpsychires.2013.09.014

43. Compton MT, Weiss PS, West JC, Kaslow NJ. The associations between substance use disorders, schizophrenia-spectrum disorders, and axis IV psychosocial problems. Soc Psychiatry Psychiatr Epidemiol (2005) 40:939-46. doi:10.1007/s00127-005-0964-4

44. Ringen PA, Melle I, Birkenaes AB, Engh JA, Faerden A, Vaskinn A, et al. The level of illicit drug use is related to symptoms and premorbid functioning in severe mental illness. Acta Psychiatr Scand (2008) 118:297-304. doi:10.1111/j.1600-0447.2008.01244.x 
45. Moos RH, Brennan PL, Mertens JR. Mortality rates and predictors of mortality among late-middle-aged and older substance abuse patients. Alcohol Clin Exp Res (1994) 18:187-95. doi:10.1111/j.1530-0277.1994.tb00902.x

46. Darke S, Kaye S, McKetin R, Duflou J. Major physical and psychological harms of methamphetamine use. Drug Alcohol Rev (2008) 27:253-62. doi:10.1080/09595230801923702

47. Lee MH, Hancox RJ. Effects of smoking cannabis on lung function. Expert Rev Respir Med (2011) 5:537-46. doi:10.1586/ers.11.40

48. Nawrot TS, Perez L, Kunzli N, Munters E, Nemery B. Public health importance of triggers of myocardial infarction: a comparative risk assessment. Lancet (2011) 377:732-40. doi:10.1016/S0140-6736(10)62296-9

49. Nordentoft M, Wahlbeck K, Hallgren J, Westman J, Osby U, Alinaghizadeh H, et al. Excess mortality, causes of death and life expectancy in 270, 770 patients with recent onset of mental disorders in Denmark, Finland and Sweden. PLoS One (2013) 8:e55176. doi:10.1371/journal.pone.0055176

50. Koola MM, McMahon RP, Wehring HJ, Liu F, Mackowick KM, Warren $\mathrm{KR}$, et al. Alcohol and cannabis use and mortality in people with schizophrenia and related psychotic disorders. J Psychiatr Res (2012) 46:987-93. doi:10.1016/j.jpsychires.2012.04.019

51. Ringen PA, Melle I, Birkenaes AB, Engh JA, Faerden A, Jonsdottir H, et al. Illicit drug use in patients with psychotic disorders compared with that in the general population: a cross-sectional study. Acta Psychiatr Scand (2008) 117:133-8. doi:10.1111/j.1600-0447.2007.01135.x

52. Gold JM, Waltz JA, Prentice KJ, Morris SE, Heerey EA. Reward processing in schizophrenia: a deficit in the representation of value. Schizophr Bull (2008) 34:835-47. doi:10.1093/schbul/sbn068

53. Kapur S, Mizrahi R, Li M. From dopamine to salience to psychosis - linking biology, pharmacology and phenomenology of psychosis. Schizophr Res (2005) 79:59-68. doi:10.1016/j.schres.2005.01.003

54. Blum K, Braverman ER, Holder JM, Lubar JF, Monastra VJ, Miller D, et al. Reward deficiency syndrome: a biogenetic model for the diagnosis and treatment of impulsive, addictive, and compulsive behaviors. J Psychoactive Drugs (2000) 32:1-112. doi:10.1080/02791072.2000.10736099

55. Batel P. Addiction and schizophrenia. Eur Psychiatry (2000) 15:115-22. doi:10.1016/S0924-9338(00)00203-0

56. Wang J, Li MD. Common and unique biological pathways associated with smoking initiation/progression, nicotine dependence, and smoking cessation. Neuropsychopharmacology (2010) 35:702-19. doi:10.1038/npp.2009.178

57. Roick C, Fritz-Wieacker AF, Matschinger H, Riedel-Heller S, Frühwald S. Health habits of patients with schizophrenia: a general pattern? Soc Psychiatry Psychiatr Epidemiol (2007) 42:268-76. doi:10.1007/s00127-007-0164-5

58. Faulkner G, Cohn T, Remington G. Validation of a physical activity assessment tool for individuals with schizophrenia. Schizophr Res (2006) 82:225-31. doi:10.1016/j.schres.2005.10.020

59. Townsend N, Bhatnagar P, Wickramashinge K, Scarborough P, Foster C, Rayner M. Physical Activity Statistics. London: British Heart Foundation (2012).

60. Beebe LH, Tian L, Goodwin A, Morris N, Swant-Allen S, Kuldau J. Effects of exercise on the mental and physical health parameters of persons with schizophrenia. Issues Ment Health Nurs (2005) 26:661-76. doi:10.1080/ 01612840590959551

61. Beebe LH, Harris RF. Description of physical activity in outpatients with schizophrenia spectrum disorders. Int J Ment Health Nurs (2013) 22:430-6. doi:10.1111/inm.12008

62. Vancampfort D, Probst M, Scheewe T, Maurissen K, Sweers K, Knapen J, et al. Lack of physical activity during leisure time contributes to an impaired health related quality of life in patients with schizophrenia. Schizophr Res (2011) 129:122-7. doi:10.1016/j.schres.2011.03.018

63. McLeod HJ, Jaques S, Deane FP. Base rates of physical activity in Australians with schizophrenia. Psychiatr Rehabil J (2009) 32:269-75. doi:10.2975/32.4. 2009.269.275

64. Blair SN, Kampert JB, Kohl HW III, Barlow CE, Macera CA, Paffenbarger RS Jr., et al. Influences of cardiorespiratory fitness and other precursors on cardiovascular disease and all-cause mortality in men and women. JAMA (1996) 276:205-10. doi:10.1001/jama.276.3.205

65. Vancampfort D, Knapen J, Probst M, Scheewe T, Remans S, De HM. A systematic review of correlates of physical activity in patients with schizophrenia. Acta Psychiatr Scand (2011) 125:352-62. doi:10.1111/j.1600-0447.2011.01814.x
66. Engh JA, Friis S, Birkenaes AB, Jonsdottir H, Klungsoyr O, Ringen PA, et al. Delusions are associated with poor cognitive insight in schizophrenia. Schizophr Bull (2010) 36:830-5. doi:10.1093/schbul/sbn193

67. Faulkner GE, Gorczynski PF, Cohn TA. Psychiatric illness and obesity: recognizing the "obesogenic" nature of an inpatient psychiatric setting. Psychiatr Serv (2009) 60:538-41. doi:10.1176/appi.ps.60.4.538

68. Lottenberg AM, Afonso MS, Lavrador MS, Machado RM, Nakandakare ER. The role of dietary fatty acids in the pathology of metabolic syndrome. J Nutr Biochem (2012) 23:1027-40. doi:10.1016/j.jnutbio.2012.03.004

69. Mann JI. Nutrition recommendations for the treatment and prevention of type 2 diabetes and the metabolic syndrome: an evidenced-based review. Nutr Rev (2006) 64:422-7. doi:10.1111/j.1753-4887.2006.tb00227.x

70. Chiuve SE, Fung TT, Rimm EB, Hu FB, McCullough ML, Wang M, et al. Alternative dietary indices both strongly predict risk of chronic disease. J Nutr (2012) 142:1009-18. doi:10.3945/jn.111.157222

71. Hu FB, Willett WC. Optimal diets for prevention of coronary heart disease. JAMA (2002) 288:2569-78. doi:10.1001/jama.288.20.2569

72. Dipasquale S, Pariante CM, Dazzan P, Aguglia E, McGuire P, Mondelli V. The dietary pattern of patients with schizophrenia: a systematic review. J Psychiatr Res (2013) 47:197-207. doi:10.1016/j.jpsychires.2012.10.005

73. Volkow ND, Wang GJ, Baler RD. Reward, dopamine and the control of food intake: implications for obesity. Trends Cogn Sci (2011) 15:37-46. doi:10.1016/j.tics.2010.11.001

74. Mennella JA. Ontogeny of taste preferences: basic biology and implications for health. Am J Clin Nutr (2014) 99:704S-11S. doi:10.3945/ajcn.113.067694

75. Mueser KT, McGurk SR. Schizophrenia. Lancet (2004) 363:2063-72. doi:10. 1016/S0140-6736(04)16458-1

76. Jarvis GE. The social causes of psychosis in North American psychiatry: a review of a disappearing literature. Can J Psychiatry (2007) 52:287-94.

77. Agerbo E, Byrne M, Eaton WW, Mortensen PB. Marital and labor market status in the long run in schizophrenia. Arch Gen Psychiatry (2004) 61:28-33. doi:10.1001/archpsyc.61.1.28

78. First MB, Tasman A. DSM-IV-TR Mental Disorders. Diagnosis, Etiology and Treatment. Chichester: Wiley (2004).

79. Green MF. What are the functional consequences of neurocognitive deficits in schizophrenia? Am J Psychiatry (1996) 153:321-30.

80. NICE. Core interventions in the treatment and management of schizophrenia in adults in primary and secondary care. London: The National Institute for Health and Clinical Excellence. (2011).

81. Rummel-Kluge C, Komossa K, Schwarz S, Hunger H, Schmid F, Lobos CA, et al. Head-to-head comparisons of metabolic side effects of second generation antipsychotics in the treatment of schizophrenia: a systematic review and metaanalysis. Schizophr Res (2010) 123:225-33. doi:10.1016/j.schres.2010.07.012

82. Allison DB, Casey DE. Antipsychotic-induced weight gain: a review of the literature. J Clin Psychiatry (2001) 62(Suppl 7):22-31.

83. Nasrallah HA. Metabolic findings from the CATIE trial and their relation to tolerability. CNS Spectr (2006) 11(7 Suppl 7):32-9.

84. Smith RC, Lindenmayer JP, Bark N, Warner-Cohen J, Vaidhyanathaswamy S, Khandat A. Clozapine, risperidone, olanzapine, and conventional antipsychotic drug effects on glucose, lipids, and leptin in schizophrenic patients. Int J Neuropsychopharmacol (2005) 8:183-94. doi:10.1017/S1461145705005110

85. De Leon J, Susce MT, Johnson M, Hardin M, Pointer L, Ruano G, et al. A clinical study of the association of antipsychotics with hyperlipidemia. Schizophr Res (2007) 92:95-102. doi:10.1016/j.schres.2007.01.015

86. Perez-Iglesias R, Crespo-Facorro B, Martinez-Garcia O, Ramirez-Bonilla ML, Alvarez-Jimenez M, Pelayo-Teran JM, et al. Weight gain induced by haloperidol, risperidone and olanzapine after 1 year: findings of a randomized clinical trial in a drug-naive population. Schizophr Res (2008) 99:13-22. doi:10.1016/j.schres.2007.10.022

87. Meduna LJ, Gerty FJ, Urse VG. Biochemical disturbances in mental disorders. Arch Neurol Psychiatry (1942) 47:38-52. doi:10.1001/archneurpsyc.1942. 02290010048004

88. Raphael TP, Parsons JP. Blood sugar studies in dementia praecox and manic depressive insanity. Arch Neurol Psychiatry (1921) 5:687-709. doi:10.1001/ archneurpsyc.1921.02180300052005

89. Maudsley H. The Pathology of Mind. 3rd ed. London: MacMillan (1879). $113 \mathrm{p}$. 
90. Planansky K. Changes in weight in patients receiving a tranquilizing drug. Psychiatr Q (1958) 32:289-303. doi:10.1007/BF01561635

91. Kroeze WK, Hufeisen SJ, Popadak BA, Renock SM, Steinberg S, Ernsberger P, et al. H1-histamine receptor affinity predicts short-term weight gain for typical and atypical antipsychotic drugs. Neuropsychopharmacology (2003) 28:519-26. doi:10.1038/sj.npp.1300292

92. Kim SF, Huang AS, Snowman AM, Teuscher C, Snyder SH. From the cover: antipsychotic drug-induced weight gain mediated by histamine $\mathrm{H} 1$ receptorlinked activation of hypothalamic AMP-kinase. Proc Natl Acad Sci U S A (2007) 104:3456-9. doi:10.1073/pnas.0611417104

93. Birkenaes AB, Birkeland KI, Friis S, Opjordsmoen S, Andreassen OA. Hormonal markers of metabolic dysregulation in patients with severe mental disorders after olanzapine treatment under real-life conditions. J Clin Psychopharmacol (2009) 29:109-16. doi:10.1097/JCP.0b013e31819b95fc

94. Dieset I, Hope S, Ueland T, Bjella T, Agartz I, Melle I, et al. Cardiovascular risk factors during second generation antipsychotic treatment are associated with increased C-reactive protein. Schizophr Res (2012) 140:169-74. doi:10.1016/j.schres.2012.06.040

95. Birkenaes AB, Birkeland KI, Engh JA, Faerden A, Jonsdottir H, Ringen $\mathrm{PA}$, et al. Dyslipidemia independent of body mass in antipsychotic-treated patients under real-life conditions. J Clin Psychopharmacol (2008) 28:132-7. doi:10.1097/JCP.0b013e318166c4f7

96. Vik-Mo AO, Birkenaes AB, Ferno J, Jonsdottir H, Andreassen OA, Steen VM. Increased expression of lipid biosynthesis genes in peripheral blood cells of olanzapine-treated patients. Int J Neuropsychopharmacol (2008) 11:679-84. doi:10.1017/S1461145708008468

97. Khan A, Faucett J, Morrison S, Brown WA. Comparative mortality risk in adult patients with schizophrenia, depression, bipolar disorder, anxiety disorders, and attention-deficit/hyperactivity disorder participating in psychopharmacology clinical trials. JAMA Psychiatry (2013) 70:1091-9. doi:10.1001/ jamapsychiatry.2013.149

98. Tiihonen J, Lonnqvist J, Wahlbeck K, Klaukka T, Niskanen L, Tanskanen A, et al. 11-year follow-up of mortality in patients with schizophrenia: a population-based cohort study (FIN11 study). Lancet (2009) 374:620-7. doi:10.1016/S0140-6736(09)60742-X

99. Kiviniemi M, Suvisaari J, Koivumaa-Honkanen H, Hakkinen U, Isohanni M, Hakko H. Antipsychotics and mortality in first-onset schizophrenia: prospective Finnish register study with 5-year follow-up. Schizophr Res (2013) 150:274-80. doi:10.1016/j.schres.2013.07.043

100. Weinmann S, Read J, Aderhold V. Influence of antipsychotics on mortality in schizophrenia: systematic review. Schizophr Res (2009) 113:1-11. doi:10.1016/j.schres.2009.05.018

101. De Hert M, Correll CU, Cohen D. Do antipsychotic medications reduce or increase mortality in schizophrenia? A critical appraisal of the FIN-11 study. Schizophr Res (2010) 117:68-74. doi:10.1016/j.schres.2009.12.029

102. Straus SM, Bleumink GS, Dieleman JP, van der Lei J, 't Jong GW, Kingma JH, et al. Antipsychotics and the risk of sudden cardiac death. Arch Intern Med (2004) 164:1293-7. doi:10.1001/archinte.164.12.1293

103. Reilly JG, Ayis SA, Ferrier IN, Jones SJ, Thomas SH. Thioridazine and sudden unexplained death in psychiatric in-patients. Br J Psychiatry (2002) 180:515-22. doi:10.1192/bjp.180.6.515

104. Ray WA, Chung CP, Murray KT, Hall K, Stein CM. Atypical antipsychotic drugs and the risk of sudden cardiac death. N Engl J Med (2009) 360:225-35. doi:10.1056/NEJMoa0806994

105. Manu P, Kane JM, Correll CU. Sudden deaths in psychiatric patients. J Clin Psychiatry (2011) 72:936-41. doi:10.4088/JCP.10m06244gry

106. Petersen L, Sorensen TI. Studies based on the Danish Adoption Register: schizophrenia, BMI, smoking, and mortality in perspective. Scand. J Public Health (2011) 39:191-5. doi:10.1177/1403494810396560

107. Andreassen OA, Djurovic S, Thompson WK, Schork AJ, Kendler KS, O'Donovan MC, et al. Improved detection of common variants associated with schizophrenia by leveraging pleiotropy with cardiovascular-disease risk factors. Am J Hum Genet (2013) 92:197-209. doi:10.1016/j.ajhg.2013.01.001

108. Andreassen OA, McEvoy LK, Thompson WK, Wang Y, Reppe S, Schork AJ, et al. Identifying common genetic variants in blood pressure due to polygenic pleiotropy with associated phenotypes. Hypertension (2014) 63:819-26. doi:10.1161/HYPERTENSIONAHA.113.02077
109. Chen S, Broqueres-You D, Yang G, Wang Z, Li Y, Wang N, et al. Relationship between insulin resistance, dyslipidaemia and positive symptom in Chinese antipsychotic-naive first-episode patients with schizophrenia. Psychiatry Res (2013) 210:825-9. doi:10.1016/j.psychres.2013.08.056

110. Harris LW, Guest PC, Wayland MT, Umrania Y, Krishnamurthy D, Rahmoune H, et al. Schizophrenia: metabolic aspects of aetiology, diagnosis and future treatment strategies. Psychoneuroendocrinology (2013) 38:752-66. doi:10.1016/j.psyneuen.2012.09.009

111. Vestri HS, Maianu L, Moellering DR, Garvey WT. Atypical antipsychotic drugs directly impair insulin action in adipocytes: effects on glucose transport, lipogenesis, and antilipolysis. Neuropsychopharmacology (2007) 32:765-72. doi:10.1038/sj.npp.1301142

112. Hahn M, Chintoh A, Giacca A, Xu L, Lam L, Mann S, et al. Atypical antipsychotics and effects of muscarinic, serotonergic, dopaminergic and histaminergic receptor binding on insulin secretion in vivo: an animal model. Schizophr Res (2011) 131:90-5. doi:10.1016/j.schres.2011.06.004

113. Stunes AK, Reseland JE, Hauso O, Kidd M, Tommeras K, Waldum HL, et al. Adipocytes express a functional system for serotonin synthesis, reuptake and receptor activation. Diabetes Obes Metab (2011) 13:551-8. doi:10.1111/j.14631326.2011.01378.x

114. Mondelli V, Cattaneo A, Belvederi MM, Di FM, Handley R, Hepgul N, et al. Stress and inflammation reduce brain-derived neurotrophic factor expression in first-episode psychosis: a pathway to smaller hippocampal volume. J Clin Psychiatry (2011) 72:1677-84. doi:10.4088/JCP.10m06745

115. Bradley AJ, Dinan TG. A systematic review of hypothalamic-pituitary-adrenal axis function in schizophrenia: implications for mortality. J Psychopharmacol (2010) 24:91-118. doi:10.1177/1359786810385491

116. Miller BJ, Buckley P, Seabolt W, Mellor A, Kirkpatrick B. Meta-analysis of cytokine alterations in schizophrenia: clinical status and antipsychotic effects. Biol Psychiatry (2011) 70:663-71. doi:10.1016/j.biopsych.2011.04.013

117. Potvin S, Stip E, Sepehry AA, Gendron A, Bah R, Kouassi E. Inflammatory cytokine alterations in schizophrenia: a systematic quantitative review. Biol Psychiatry (2008) 63:801-8. doi:10.1016/j.biopsych.2007.09.024

118. Corrado E, Rizzo M, Coppola G, Fattouch K, Novo G, Marturana I, et al. An update on the role of markers of inflammation in atherosclerosis. J Atheroscler Thromb (2010) 17:1-11. doi:10.5551/jat.2600

119. Leonard BE, Schwarz M, Myint AM. The metabolic syndrome in schizophrenia: is inflammation a contributing cause? J Psychopharmacol (2012) 26:33-41. doi:10.1177/0269881111431622

120. Bradford DW, Kim MM, Braxton LE, Marx CE, Butterfield M, Elbogen EB. Access to medical care among persons with psychotic and major affective disorders. Psychiatr Serv (2008) 59:847-52. doi:10.1176/appi.ps.59.8.847

121. Kilbourne AM, McCarthy JF, Welsh D, Blow F. Recognition of co-occurring medical conditions among patients with serious mental illness. J Nerv Ment Dis (2006) 194:598-602. doi:10.1097/01.nmd.0000230637.21821.ec

122. Mitchell AJ, Lord O, Malone D. Differences in the prescribing of medication for physical disorders in individuals with $\mathrm{v}$. without mental illness: meta-analysis. Br J Psychiatry (2012) 201:435-43. doi:10.1192/bjp.bp.111.094532

123. Salsberry PJ, Chipps E, Kennedy C. Use of general medical services among Medicaid patients with severe and persistent mental illness. Psychiatr Serv (2005) 56:458-62. doi:10.1176/appi.ps.56.4.458

124. Copeland LA, Zeber JE, Wang CP, Parchman ML, Lawrence VA, Valenstein M, et al. Patterns of primary care and mortality among patients with schizophrenia or diabetes: a cluster analysis approach to the retrospective study of healthcare utilization. BMC Health Serv Res (2009) 9:127. doi:10.1186/1472-6963-9-127

125. Roberts L, Roalfe A, Wilson S, Lester H. Physical health care of patients with schizophrenia in primary care: a comparative study. Fam Pract (2007) 24:34-40. doi:10.1093/fampra/cml054

126. Mitchell AJ, Lord O. Do deficits in cardiac care influence high mortality rates in schizophrenia? A systematic review and pooled analysis. J Psychopharmacol (2010) 24:69-80. doi:10.1177/1359786810382056

127. Hippisley-Cox J, Parker C, Coupland C, Vinogradova Y. Inequalities in the primary care of patients with coronary heart disease and serious mental health problems: a cross-sectional study. Heart (2007) 93:1256-62. doi:10.1136/hrt. 2006.110171

128. Marchand WE. Occurrence of painless myocardial infarction in psychotic patients. N Engl J Med (1955) 253:51-5. doi:10.1056/NEJM195507142530202 
129. Rosenthal SH, Porter KA, Coffey B. Pain insensitivity in schizophrenia. Case report and review of the literature. Gen Hosp Psychiatry. (1990) 12:319-22. doi:10.1016/0163-8343(90)90050-M

130. Potvin S, Marchand S. Hypoalgesia in schizophrenia is independent of antipsychotic drugs: a systematic quantitative review of experimental studies. Pain (2008) 138:70-8. doi:10.1016/j.pain.2007.11.007

131. Hooley JM, Delgado ML. Pain insensitivity in the relatives of people with schizophrenia. Schizophr Res (2001) 47:265-73. doi:10.1016/S0920-9964(00) 00064-5

132. Bickerstaff LK, Harris SC, Leggett RS, Cheah KC. Pain insensitivity in schizophrenic patients a surgical dilemma. Arch Surg. (1988) 123:49-51. doi:10.1001/ archsurg.1988.01400250059010

133. Wylie KP, Tregellas JR. The role of the insula in schizophrenia. Schizophr Res (2010) 123:93-104. doi:10.1016/j.schres.2010.08.027

134. Daumit GL, Crum RM, Guallar E, Ford DE. Receipt of preventive medical services at psychiatric visits by patients with severe mental illness. Psychiatr Serv (2002) 53:884-7. doi:10.1176/appi.ps.53.7.884

135. Rasanen S, Hakko H, Viilo K, Meyer-Rochow VB, Moring J. Excess mortality among long-stay psychiatric patients in Northern Finland. Soc Psychiatry Psychiatr Epidemiol (2003) 38:297-304. doi:10.1007/s00127-003-0635-2

136. Hart C, Gruer L, Bauld L. Does smoking reduction in midlife reduce mortality risk? Results of 2 long-term prospective cohort studies of men and women in Scotland. Am J Epidemiol (2013) 178:770-9. doi:10.1093/aje/kwt038

137. Gerber Y, Myers V, Goldbourt U. Smoking reduction at midlife and lifetime mortality risk in men: a prospective cohort study. Am J Epidemiol (2012) 175:1006-12. doi:10.1093/aje/kwr466

138. Bennett ME, Wilson AL, Genderson M, Saperstein AM. Smoking cessation in people with schizophrenia. Curr Drug Abuse Rev (2013) 6:180-90. doi:10.2174/18744737112059990011

139. Hahn B, Harvey AN, Concheiro-Guisan M, Huestis MA, Holcomb HH, Gold JM. A test of the cognitive self-medication hypothesis of tobacco smoking in schizophrenia. Biol Psychiatry (2013) 74:436-43. doi:10.1016/j.biopsych.2013. 03.017

140. Ragg M, Gordon R, Ahmed T, Allan J. The impact of smoking cessation on schizophrenia and major depression. Australas Psychiatry (2013) 21:238-45. doi:10.1177/1039856213486213

141. Tsoi DT, Porwal M, Webster AC. Interventions for smoking cessation and reduction in individuals with schizophrenia. Cochrane Database Syst Rev (2013) 2:CD007253. doi:10.1002/14651858.CD007253

142. Pagels P, Raustorp A, Archer T, Lidman U, Alricsson M. Influence of moderate, daily physical activity upon body composition and blood lipid profile in Swedish adults. J Phys Act Health (2011) 9:867-74.

143. Lavie CJ, Thomas RJ, Squires RW, Allison TG, Milani RV. Exercise training and cardiac rehabilitation in primary and secondary prevention of coronary heart disease. Mayo Clin Proc (2009) 84:373-83. doi:10.1016/S0025-6196(11) 60548-X

144. Dodd KJ, Duffy S, Stewart JA, Impey J, Taylor N. A small group aerobic exercise programme that reduces body weight is feasible in adults with severe chronic schizophrenia: a pilot study. Disabil Rehabil (2011) 33:1222-9. doi:10.3109/09638288.2010.526162

145. Gorczynski P, Faulkner G. Exercise therapy for schizophrenia. Cochrane Database Syst Rev (2010) 5:CD004412. doi:10.1002/14651858.CD004412.pub2

146. Wildgust HJ, Beary M. Are there modifiable risk factors which will reduce the excess mortality in schizophrenia? J Psychopharmacol (2010) 24:37-50. doi: $10.1177 / 1359786810384639$

147. Porsdal V, Beal C, Kleivenes OK, Martinsen EW, Lindstrom E, Nilsson H, et al. The Scandinavian Solutions for Wellness study - a two-arm observational study on the effectiveness of lifestyle intervention on subjective well-being and weight among persons with psychiatric disorders. BMC Psychiatry (2010) 10:42. doi:10.1186/1471-244X-10-42

148. Beebe LH, Smith K, Burk R, McIntyre K, Dessieux O, Tavakoli A, et al. Effect of a motivational intervention on exercise behavior in persons with schizophrenia spectrum disorders. Community Ment Health J (2011) 47:628-36. doi:10.1007/s10597-010-9363-8

149. Daumit GL, Dalcin AT, Jerome GJ, Young DR, Charleston J, Crum RM, et al. A behavioral weight-loss intervention for persons with serious mental illness in psychiatric rehabilitation centers. Int J Obes (Lond) (2011) 35:1114-23. doi:10.1038/ijo.2010.224
150. Ganguli R. Behavioral therapy for weight loss in patients with schizophrenia. J Clin Psychiatry (2007) 68(Suppl 4):19-25.

151. Methapatara W, Srisurapanont M. Pedometer walking plus motivational interviewing program for Thai schizophrenic patients with obesity or overweight: a 12-week, randomized, controlled trial. Psychiatry Clin Neurosci (2011) 65:374-80. doi:10.1111/j.1440-1819.2011.02225.x

152. Kodama S, Saito K, Tanaka S, Maki M, Yachi Y, Asumi M, et al. Cardiorespiratory fitness as a quantitative predictor of all-cause mortality and cardiovascular events in healthy men and women: a meta-analysis. JAMA (2009) 301:2024-35. doi:10.1001/jama.2009.681

153. Heggelund J, Nilsberg GE, Hoff J, Morken G, Helgerud J. Effects of high aerobic intensity training in patients with schizophrenia: a controlled trial. Nord J Psychiatry (2011) 65:269-75. doi:10.3109/08039488.2011.560278

154. Scheewe TW, Backx FJ, Takken T, Jorg F, van Strater AC, Kroes AG, et al. Exercise therapy improves mental and physical health in schizophrenia: a randomised controlled trial. Acta Psychiatr Scand (2013) 127:464-73. doi:10.1111/acps. 12029

155. Schwingshackl L, Hoffmann G. Comparison of the long-term effects of highfat v. low-fat diet consumption on cardiometabolic risk factors in subjects with abnormal glucose metabolism: a systematic review and meta-analysis. Br J Nutr (2014) 111:2047-58. doi:10.1017/S0007114514000464

156. Esposito K, Kastorini CM, Panagiotakos DB, Giugliano D. Mediterranean diet and metabolic syndrome: an updated systematic review. Rev Endocr Metab Disord (2013) 14:255-63. doi:10.1007/s11154-013-9253-9

157. Bueno NB, de Melo IS, de Oliveira SL, da Rocha AT. Very-low-carbohydrate ketogenic diet v. low-fat diet for long-term weight loss: a meta-analysis of randomised controlled trials. Br J Nutr (2013) 110:1178-87. doi:10.1017/ S0007114513000548

158. Lee SJ, Choi EJ, Kwon JS. A naturalistic multicenter trial of a 12-week weight management program for overweight and obese patients with schizophrenia or schizoaffective disorder. J Clin Psychiatry (2008) 69:555-62. doi:10.4088/JCP.v69n0406

159. Melamed Y, Stein-Reisner O, Gelkopf M, Levi G, Sivan T, Ilievici G, et al. Multimodal weight control intervention for people with persistent mental disorders. Psychiatr Rehabil J (2008) 31:194-200. doi:10.2975/31.3.2008.194.200

160. Menza M, Vreeland B, Minsky S, Gara M, Radler DR, Sakowitz M. Managing atypical antipsychotic-associated weight gain: 12-month data on a multimodal weight control program. J Clin Psychiatry (2004) 65:471-7. doi:10.4088/JCP.v65n0404

161. Faulkner G, Cohn T, Remington G. Interventions to reduce weight gain in schizophrenia. Cochrane Database Syst Rev (2007) 1:CD005148. doi:10.1002/ 14651858.CD005148.pub2

162. Powers PS, Cloak NL. Psychopharmacologic treatment of obesity and eating disorders in children and adolescents. Child Adolesc Psychiatr Clin NAm (2012) 21:831-59. doi:10.1016/j.chc.2012.07.003

163. Smith SM, Meyer M, Trinkley KE. Phentermine/topiramate for the treatment of obesity. Ann Pharmacother (2013) 47:340-9. doi:10.1345/aph.1R501

164. Johansson K, Neovius M, Hemmingsson E. Effects of anti-obesity drugs, diet, and exercise on weight-loss maintenance after a very-low-calorie diet or low-calorie diet: a systematic review and meta-analysis of randomized controlled trials. Am J Clin Nutr (2014) 99:14-23. doi:10.3945/ajcn.113. 070052

165. Vincenzi B, Borba CP, Gray DA, Copeland PM, Wang X, Fan X, et al. An exploratory study examining lipid-lowering medications in reducing fasting serum lipids in people with schizophrenia treated with atypical antipsychotics. Ann Clin Psychiatry (2013) 25:141-8.

166. Heymsfield SB, Greenberg AS, Fujioka K, Dixon RM, Kushner R, Hunt T, et al. Recombinant leptin for weight loss in obese and lean adults: a randomized, controlled, dose-escalation trial. JAMA (1999) 282:1568-75. doi:10.1001/jama. 282.16.1568

167. Korner J, Conroy R, Febres G, McMahon DJ, Conwell I, Karmally W, et al. Randomized double-blind placebo-controlled study of leptin administration after gastric bypass. Obesity (Silver Spring) (2013) 21:951-6. doi:10. 1002/oby.20433

168. Amrami-Weizman A, Maayan R, Gil-Ad I, Pashinian A, Fuchs C, Kotler M, et al. The effect of reboxetine co-administration with olanzapine on metabolic and endocrine profile in people with schizophrenia. Psychopharmacology (Berl) (2013) 230:23-7. doi:10.1007/s00213-013-3199-1 
169. Tek C, Guloksuz S, Srihari VH, Reutenauer EL. Investigating the safety and efficacy of naltrexone for anti-psychotic induced weight gain in severe mental illness: study protocol of a double-blind, randomized, placebo-controlled trial. BMC Psychiatry (2013) 13:176. doi:10.1186/1471-244X-13-176

170. Das C, Mendez G, Jagasia S, Labbate LA. Second-generation antipsychotic use in schizophrenia and associated weight gain: a critical review and metaanalysis of behavioral and pharmacologic treatments. Ann Clin Psychiatry (2012) 24:225-39. doi:10.1093/schbul/sbu030

171. Mizuno Y, Suzuki T, Nakagawa A, Yoshida K, Mimura M, Fleischhacker WW, et al. Pharmacological strategies to counteract antipsychotic-induced weight gain and metabolic adverse effects in schizophrenia: a systematic review and meta-analysis. Schizophr Bull (2014). doi:10.1093/schbul/sbu030

172. Maayan L, Vakhrusheva J, Correll CU. Effectiveness of medications used to attenuate antipsychotic-related weight gain and metabolic abnormalities: a systematic review and meta-analysis. Neuropsychopharmacology (2010) 35:1520-30. doi:10.1038/npp.2010.21

173. Yanovski SZ, Yanovski JA. Long-term drug treatment for obesity: a systematic and clinical review. JAMA (2014) 311:74-86. doi:10.1001/jama.2013. 281361

174. Gloy VL, Briel M, Bhatt DL, Kashyap SR, Schauer PR, Mingrone G, et al. Bariatric surgery versus non-surgical treatment for obesity: a systematic review and meta-analysis of randomised controlled trials. BMJ (2013) 347:f5934. doi:10.1136/bmj.f5934

175. Hamoui N, Kingsbury S, Anthone GJ, Crookes PF. Surgical treatment of morbid obesity in schizophrenic patients. Obes Surg (2004) 14:349-52. doi:10. 1381/096089204322917873

176. American Diabetes Association, American Psychiatric Association, American Association of Clinical Endocrinologists, North American Association for the Study of Obesity. Consensus development conference on antipsychotic drugs and obesity and diabetes. J Clin Psychiatry (2004) 2:267-72. doi:10.4088/JCP.v65n0219

177. Morrato EH, Newcomer JW, Kamat S, Baser O, Harnett J, Cuffel B. Metabolic Screening After the American Diabetes Association's Consensus Statement on Antipsychotic Drugs and Diabetes. Diabetes Care (2009) 32:1037-42. doi: $10.2337 / \mathrm{dc} 08-1720$

178. Miller WR, Rollnick S. Ten things that motivational interviewing is not. Behav Cogn Psychother (2009) 37:129-40. doi:10.1017/S1352465809005128

179. Emmons KM, Rollnick S. Motivational interviewing in health care settings. Opportunities and limitations. Am J Prev Med (2001) 20:68-74. doi:10.1016/ S0749-3797(00)00254-3

180. Britt E, Hudson SM, Blampied NM. Motivational interviewing in health settings: a review. Patient Educ Couns (2004) 53:147-55. doi:10.1016/S07383991(03)00141-1

181. Levensky ER, Forcehimes A, O’Donohue WT, Beitz K. Motivational interviewing: an evidence-based approach to counseling helps patients follow treatment recommendations. Am J Nurs (2007) 107:50-8. doi:10.1097/01.NAJ. 0000292202.06571 .24

182. Thompson DR, Chair SY, Chan SW, Astin F, Davidson PM, Ski CF. Motivational interviewing: a useful approach to improving cardiovascular health? J Clin Nurs (2011) 20:1236-44. doi:10.1111/j.1365-2702.2010.03558.x

183. Gorczynski P, Faulkner G, Greening S, Cohn T. Exploring the construct validity of the transtheoretical model to structure physical activity interventions for individuals with serious mental illness. Psychiatr Rehabil J (2010) 34:61-4. doi:10.2975/34.1.2010.61.64

184. Roberts SH, Bailey JE. Incentives and barriers to lifestyle interventions for people with severe mental illness: a narrative synthesis of quantitative, qualita- tive and mixed methods studies. J Adv Nurs (2011) 67:690-708. doi:10.1111/j. 1365-2648.2010.05546.x

185. Burghardt KJ, Ellingrod VL. Detection of metabolic syndrome in schizophrenia and implications for antipsychotic therapy: is there a role for folate? $\mathrm{Mol}$ Diagn Ther (2013) 17:21-30. doi:10.1007/s40291-013-0017-8

186. Hasan A, Falkai P, Wobrock T, Lieberman J, Glenthoj B, Gattaz WF, et al. World Federation of Societies of Biological Psychiatry (WFSBP) guidelines for biological treatment of schizophrenia, part 2: update 2012 on the longterm treatment of schizophrenia and management of antipsychotic-induced side effects. World J Biol Psychiatry (2013) 14:2-44. doi:10.3109/15622975. 2012.739708

187. Mitchell AJ, Delaffon V, Vancampfort D, Correll CU, De HM. Guideline concordant monitoring of metabolic risk in people treated with antipsychotic medication: systematic review and meta-analysis of screening practices. Psychol Med (2012) 42:125-47. doi:10.1017/S003329171100105X

188. Gaebel W, Riesbeck M, Wobrock T. Schizophrenia guidelines across the world: a selective review and comparison. Int Rev Psychiatry (2011) 23:379-87. doi:10.3109/09540261.2011.606801

189. Perez-Iglesias R, Martinez-Garcia O, Pardo-Garcia G, Amado JA, GarciaUnzueta MT, Tabares-Seisdedos R, et al. Course of weight gain and metabolic abnormalities in first treated episode of psychosis: the first year is a critical period for development of cardiovascular risk factors. Int J Neuropsychopharmacol (2014) 17:41-51. doi:10.1017/S1461145713001053

190. De Hert M, Dekker JM, Wood D, Kahl KG, Holt RI, Moller HJ. Cardiovascular disease and diabetes in people with severe mental illness position statement from the European psychiatric association (EPA), supported by the European association for the study of diabetes (EASD) and the European society of cardiology (ESC). Eur Psychiatry (2009) 24:412-24. doi:10.1016/j.eurpsy.2009.01. 005

191. Casey DA, Rodriguez M, Northcott C, Vickar G, Shihabuddin L. Schizophrenia: medical illness, mortality, and aging. Int J Psychiatry Med (2011) 41:245-51. doi:10.2190/PM.41.3.c

192. Vreeland B. Bridging the gap between mental and physical health: a multidisciplinary approach. J Clin Psychiatry (2007) 68(Suppl 4):26-33.

193. Crompton D, Groves A, McGrath J. What can we do to reduce the burden of avoidable deaths in those with serious mental illness? Epidemiol Psichiatr Soc (2010) 19(1):4-7.

Conflict of Interest Statement: The authors declare that the research was conducted in the absence of any commercial or financial relationships that could be construed as a potential conflict of interest.

Received: 13 April 2014; accepted: 12 September 2014; published online: 26 September 2014.

Citation: Ringen PA, Engh JA, Birkenaes AB, Dieset I and Andreassen OA (2014) Increased mortality in schizophrenia due to cardiovascular disease - a non-systematic review of epidemiology, possible causes, and interventions. Front. Psychiatry 5:137. doi: 10.3389/fpsyt.2014.00137

This article was submitted to Schizophrenia, a section of the journal Frontiers in Psychiatry.

Copyright (c) 2014 Ringen, Engh, Birkenaes, Dieset and Andreassen. This is an openaccess article distributed under the terms of the Creative Commons Attribution License (CC BY). The use, distribution or reproduction in other forums is permitted, provided the original author(s) or licensor are credited and that the original publication in this journal is cited, in accordance with accepted academic practice. No use, distribution or reproduction is permitted which does not comply with these terms. 